\title{
Site Factors and Management Practices Associated with the Incidence of Blight in Chestnut Orchards in Northeastern Portugal
}

\author{
E. Portela and R. Pinto \\ Department of Edaphology \\ University of Trás-os-Montes and Alto Douro, Vila Real, Portugal
}

\begin{abstract}
The objective of this study was to identify the possible relationship between management practices and site factors with the incidence of blight in chestnut orchards. The survey took place in the two ecological sub-regions of Padrela and Bragança in NE Portugal. A total of 62 farmers were questioned about management practices and 107 orchards were described for site characteristics and evaluated for blight disease. Statistical analyses were carried out both for discrete and continuous variables in order to determine the association between these and the presence of disease in healthy orchards $(<10 \%$ of incidence) and diseased orchards $(>10 \%$ incidence). Chestnut blight occurs more often in orchards located in soils derived from granite and quartzite schist, on plateau and convex slopes and in orchards established on previously uncultivated land (moorland). No relationship was found between disease incidence and slope aspect, soil drainage or soil stoniness. The blight incidence was higher in orchards submitted to more tillage operations $(\geq 3$ per year); less frequent pruning (3-4 years, i. e. larger branches) when compared to more frequent pruning (1-2 years, i. e. twigs); heavy application of farmyard manures; higher $N$ and $P$ application rates both from organic and mineral fertilisers.
\end{abstract}

\section{INTRODUCTION}

Chestnut blight (caused by Cryphonectria parasitica) (Murr.) Barr was first observed in Portugal in the 80's (Abreu, 1992a) in Trás-os-Montes (NE Portugal) and nowadays is causing considerable damage to chestnut orchards (Castanea sativa Mill.). In the last two decades the increased demand for nuts has led to more intensive management and to the establishment of new chestnut orchards in soils with severe limitations and with low site fertility. The effects of the intensification of management practices are evident in the increase of blight incidence and severity. Gouveia et al. (2001) consider that grafting and pruning play an important role in spreading the disease. Many farmers also have the perception (Portela and Pinto, 2004) that pruning is one of the practices that most contributes to blight occurrence. The 3-year program for the eradication of chestnut blight, implemented since 1998, has not been effective, and blight is a widespread disease in this region with an overall incidence of $10 \%$ (Anastácio et al., 2001 ), and in some orchards with $100 \%$ of trees infected. A number of chestnut orchards severely attacked with blight can be found side by side with healthy orchards, though climatic and lithological conditions are the same. This suggests that orchard management or some interaction between site factors and management practices might be associated with the disease. 
There is a lack of empirical work in this subject, so the objective of this study was to identify the possible relationship between management practices and site factors with the incidence of blight in chestnut orchards.

\section{MATERIALS AND METHODS}

\section{Study Area: Topography, Climate and Soils}

The study was carried out in the two ecological sub-regions of Padrela and Bragança (Trás-os-Montes) at 700-900 m elevation. The orchards were located in flat to hilly topography and most slopes were south-facing.

Mean annual precipitation within the surveyed area ranges from 700 to $1200 \mathrm{~mm}$ and the rainfall is the main climatic constraint. Its distribution can be erratic, with dry spells in spring and summer. Temperatures are mild most of the year (annual mean in the range of $11{ }^{\circ} \mathrm{C}-13{ }^{\circ} \mathrm{C}$ ).

The soils are well drained, with textures from loamy sand to silty loam. Underlying rock materials are base-poor granite and quartzite schist and with the majority being acid schists: mica schist, quartz-phyllite, phyllite, graywake and chlorite schist. Coarse fragments are present in all soils, with a high percentage of gravel in soils derived from granite, but with large boulders in soils derived from quartzite schist. Most soil units are umbric Cambisols and Leptosols derived from granites and schists, and distric Cambisols and Leptosols derived from schists and a very few are chromic Luvisols (Agroconsultores-Coba, 1991).

\section{Selection of Chestnut Orchards}

A total of 107 orchards showing varying degrees of blight incidence were selected. The initial foci of blight disease (Abreu, 1992b) were included in the surveyed area. Judia was the main chestnut variety followed by Longal, the first being the dominant variety in the areas most affected with blight (Anastácio et al., 2001; Portela and Pinto, 2004). The age of the orchards varied from 10 to about 50 years-old with $78 \%$ being between 10 to 25 years old. In each orchard the percentage of trees infected by blight (caused by Cryphonectria parasitica) was determined. For the purpose of statistical analysis the orchards were classed according to blight incidence into two groups: 'healthy orchard' (H-orchard) had $<10 \%$ of trees infected and 'diseased orchard' (D-orchard) had $>10 \%$ of trees infected.

\section{Data Collection and Analysis}

A total of 62 farmers were interviewed in depth during 2002. The questionnaire used contained both open and closed-end questions about past and actual (2001-2002) management practices (MP) such as: previous land-use, tillage operations, pruning, grafting, fertilisation (type, amount and frequency) and preventive measures to control blight. The site characterisation of the 107 orchards was described for landform and topography, lithology, surface stoniness and drainage according to FAO-ISRIC (1990).

To investigate the relationship between blight with site characteristics and MP, the chestnut orchards were categorised into the two groups defined earlier (H-orchard and D-orchard) and were submitted to a cross statistical analysis. The association between the disease incidence and each of the categorical variables was assessed via chi-squared tests. The distribution of continuous variables in each of the groups was determined by analysis 
of variance (ANOVA) and Duncan pairwise comparison of means. SPSS 11 was used in the analysis.

\section{RESULTS AND DISCUSSION}

The statistical results referring to the association between chestnut blight with site factors and MP are displayed in Table 1. Only those variables for which the statistical analysis gave significant differences for $\mathrm{p}<0.10$ were displayed.

The underlying rock and land form is shown to have a significant influence on blight occurrence. The incidence of blight was higher in orchards established in quartzite schist and granite. These two materials produce very coarse textured soils, with very low nutrient reserves and water holding capacity. It is worth noting that the first focus of blight, observed in Bragança by regional services in 1989, was in orchards established in quartzite schist (Portela and Pinto, 2004). In addition, the orchards positioned on the convex slope, upper slope, crest and plateau (several orchards on granite) have low soil depth, therefore the chestnuts are shallow rooted and consequently have poor reserves of water and nutrients.

The past land use is also relevant in explaining the incidence of blight. When chestnuts follow a rye crop they seem to be less affected by the disease than when orchards are installed on uncultivated land. Recently, due to the increased demand for chestnuts and because this is an important source of income for farmers in the region, moorland and pine forest land are being planted with chestnut (19\% of the orchards recently established). However, in most cases, these lands have severe limitations for tree growth because soils are shallow and derived from a base-poor parent material. In the current study, other land characteristics, such as the slope aspect, drainage and the presence of coarse fragments were not associated with blight occurrence.

In summary, parent material, the relative orchard position and past land use may create rather poor growth conditions. Indeed, it would seem that some orchards are established in the wrong place, due to severe soil limitations related to hydrological conditions and chestnut nutrition.

Some MP, such as, dominant chestnut variety, grafting technique, pruning instruments, liming, boron fertilisation and treatments to infected trees were not related to blight incidence $(\mathrm{p}<0.05)$. Despite the fact that the proportion of infected trees of the Judia variety was higher compared to those of Longal, the difference was not statistically significant. However, when we analysed the data by separating the varieties in each orchard (and determined the blight incidence for each variety), and when the size of orchard is considered (i.e., a weighted mean was determined) the statistical results showed significant differences between the two varieties: blight incidence among Judia was $22 \%$ and among Longal was $10 \%(\mathrm{p}=0.0262)$. The belief that Judia was more affected by this disease emerged after the implementation of the program to eradicate chestnut blight (Anastácio et al., 2001), though the quantitative data is not available yet. As far as the grafting technique is concerned, our data was not conclusive.

The frequency of pruning is associated with less blight incidence. Some authors consider that pruning plays an important role in spreading the blight since wounds are potential invasion sites for the pathogenic fungi. So, it seems rather paradoxical that the more frequently pruned trees (every 1-2 years) had less disease incidence, as shown in the present survey. However, we ascertained from the farmers that the higher frequency of pruning is mostly of thinner branches whose wounds close faster. Probably the rapid 
healing of wounds has prevented infection. The instruments used for pruning were not shown to be related to the disease.

The incidence of blight is higher when tillage increases, as displayed in Table 1. There is no doubt about its negative effect on chestnut health due to soil and root disturbance, particularly as far as ink root disease is concerned (Portela et al., 1999; Marcelino et al., 2000). It is worth noting that shallow soils are, in general, more affected by tillage, because trees are more dependent on surface feeder roots for the uptake of nutrients and water.

The treatments applied to diseased trees also did not appear to be related to blight. However, some preventive measures, such as the protection of accidental wounds with copper compounds and/or slaked lime, seem to be effective although only a few cases were observed.

The two fertilisation practices of liming and applying boron were not associated with the disease incidence. Liming is barely carried out and boron application was accomplished on a very irregular basis, though used by most farmers. The data relating to organic and mineral fertilisation with major nutrients are displayed in Table 2 , since these items could be treated as continuous variables. The mean rates of organic manuring and nutrients applied via organic and/or mineral fertilisers are displayed for $\mathrm{H}$-orchards and D-orchards. The application rates are expressed both per tree and canopy projection area, because farmers sometimes concentrate the fertilisers around the trunk and at other times they spread it beneath the canopy. In general, the higher rates of application of organic manures (most often farmyard manures and slurries) and nutrients are associated with more diseased orchards. These rates were more or less double in D-orchards. Nitrogen and phosphorus are the nutrients that are significantly related with blight incidence. The higher contents of $\mathrm{N}$ and $\mathrm{P}$ in the bark of chestnut in the D-orchards were confirmed by chemical analysis (Portela and Louzada, 2004). Thus, overfertilisation may cause nutrient imbalance and, probably, increasing susceptibility of trees to blight. In addition, tillage may contribute to increased decomposition of organic matter and $\mathrm{N}$ and $\mathrm{P}$ mineralization. Raimundo (2003) observed seasonal increases of mineral $\mathrm{N}$ in chestnut orchards of NE Portugal following tillage operations.

In summary, our data suggest that the incidence of blight is associated with two circumstances that seems to be in opposition, and are apparently related to chestnut nutritional conditions:

- very poor soil conditions, i.e. soils derived from poor bed-rock (quartzite and granite), on convex slopes and plateau (more shallow soils) and on previously uncultivated land. These soils may have poor water holding capacity and low nutrients reserve. In addition to this poorly buffered soil environment, root disturbance by frequent tillage may also contribute to deficient tree nutrition;

- unbalanced fertilisation, i.e. excessive organic manuring and/or application of $\mathrm{N}$ and $\mathrm{P}$ fertilisers, which can stimulate tree growth beyond the capacity of the soil to supply other limiting nutrients. Moreover tillage might have contributed to an increase of $\mathrm{N}$ availability.

Besides these two nutritional conditions, the higher pruning frequency (i.e. thinner branches and twigs) and the preventive practices for protecting fortuitous wounds are both associated with less disease incidence and seem to be related to the reduction of blight infection. 


\section{ACKNOWLEDGEMENTS}

This study was supported by grants from PO-AGRO and EC. Thanks are due to C. Marques (UTAD) for advice on statistical analysis.

\section{References Cited}

Abreu, C.G. 1992a. A hipovirulência como forma natural de luta biológica contra o cancro do castanheiro. Revista de Ciências Agrárias 15:167-71.

Abreu, C.G. 1992b. Castanheiros: uma saudade no futuro? Finisterra 27 (53-54): 1-14.

Agroconsultores-Coba. 1991. Carta de Solos. Universidade de Trás-os-Montes e Alto Douro, Vila Real.

Anastácio, M.D.: Mesquita, M.M. and Ponteira, D. 2001. Programa de erradicação do cancro do castanheiro. Direcção Regional de Agricultura de Trás-os-Montes. Jornadas Transfronteiriças do Castanheiro, 11-12 Maio 2001, Bragança.

FAO-ISRIC. 1990. Guidelines for Soil Profile Description, ( $3^{\text {rd }}$ ed). FAO, Rome.

Gouveia, M.E.; Cardoso, P. and Monteiro, M.L. 2001. Incidence of chestnut blight and diversity of vegetative compatible types of Cryphonectria parasitica in Trás-osMontes (Portugal). For. Snow Landsc. Res.76: 387-390.

Marcelino, V.; Torres, N.; Portela, E. and Martins, A. 2000. Soil physical properties and the occurrence of chestnut disease: a micromorphological study. Ecologia Mediterranea 26: 1229-136.

Portela, E.; Aranha, J.; Martins, A. and Pires, A.L. 1999. Soil factors, farmer's practices and chestnut ink disease: some interactions. Abstracts of the Second International Chestnut Symposium, October 19-23, Bordeaux, France.

Portela, E. and Louzada, J. 2004. Estado nutritivo dos soutos e incidência do cancro do castanheiro. Pp. 135-141. Nutrição Mineral: Causas e Consequências da Dependência da Fertilização, X Simpósio Ibérico de Nutrição Mineral das Plantas, 21-24 Setembro, Lisboa.

Portela, E. and Pinto, R. 2004. Práticas Culturais em Soutos de Trás-os-Montes e Relação com a Incidência do Cancro. Project report AGRO 151. UTAD, Vila Real.

Raimundo, F. 2003. Sistemas de Mobilização do Solo em Soutos. Ph.D dissertation presented at UTAD. Universidade de Trás-os-Montes e Alto Douro, Vila Real. 


\section{Tables}

Table1-Association between site factors and MP with the incidence of blight in orchards in Trás-os-Montes. The data was collected in 2001/2002. Variables for which the statistical analysis were significant for $\mathrm{p}<0.10$

\begin{tabular}{|c|c|c|c|c|c|}
\hline \multirow[b]{2}{*}{ Variable } & \multirow[b]{2}{*}{ Category } & \multirow[b]{2}{*}{$\begin{array}{l}\mathbf{N}^{\circ} \text { of } \\
\text { obser- } \\
\text { vations } \\
\text { total }=107\end{array}$} & \multicolumn{2}{|c|}{ \% of observations } & \multirow[b]{2}{*}{$\mathbf{p}$} \\
\hline & & & $\begin{array}{l}\text { H-orchards } \\
<10 \% \text { trees } \\
\text { infected } \\
n=51\end{array}$ & $\begin{array}{l}\text { D-orchards } \\
>10 \% \text { trees } \\
\text { infected } \\
n=56\end{array}$ & \\
\hline \multirow{3}{*}{ lithology } & schists & 74 & 55 & 45 & \multirow{3}{*}{0.050} \\
\hline & quartzíte schist & 5 & 40 & 60 & \\
\hline & granite & 28 & 29 & 71 & \\
\hline \multirow{4}{*}{ slope form } & convex slope or plateau & 65 & 37 & 63 & \multirow{4}{*}{0.003} \\
\hline & concave slope & 14 & 86 & 14 & \\
\hline & straight slope & 23 & 61 & 39 & \\
\hline & flat to concave & 5 & 20 & 80 & \\
\hline \multirow{4}{*}{ previous crop } & moorland & 19 & 32 & 68 & \multirow{4}{*}{0.027} \\
\hline & potato or maize $\mathrm{x}$ rye & 50 & 40 & 60 & \\
\hline & rye $\mathrm{x}$ fallow & 30 & 70 & 30 & \\
\hline & other & 7 & 43 & 57 & \\
\hline \multirow{4}{*}{ grafting technique } & flute & 83 & 45 & 55 & \multirow{4}{*}{0.071} \\
\hline & whip and tongue & 15 & 60 & 40 & \\
\hline & budding & 6 & 83 & 17 & \\
\hline & other & 3 & 0 & 100 & \\
\hline \multirow{3}{*}{ pruning frequency } & $1-2$ years & 14 & 79 & 21 & \multirow{3}{*}{0.011} \\
\hline & 3-4 years & 77 & 39 & 61 & \\
\hline & $>4$ years & 16 & 62 & 38 & \\
\hline \multirow{3}{*}{$\begin{array}{l}\text { soil tillage per year } \\
\text { before } 2001\end{array}$} & $\leq 2$ & 48 & 62 & 38 & \multirow{3}{*}{0.019} \\
\hline & 3 & 47 & 34 & 66 & \\
\hline & $>3$ & 12 & 42 & 58 & \\
\hline \multirow{3}{*}{$\begin{array}{l}\text { soil tillage per year } \\
\text { in } 2001 / 2002\end{array}$} & $\leq 2$ & 64 & 56 & 44 & \multirow{3}{*}{0.089} \\
\hline & 3 & 36 & 36 & 64 & \\
\hline & $>3$ & 7 & 29 & 71 & \\
\hline \multirow{2}{*}{$\begin{array}{l}\text { fertilization with } \\
\text { boron before } 2001\end{array}$} & yes & 49 & 39 & 61 & \multirow{2}{*}{0.091} \\
\hline & no & 58 & 61 & 45 & \\
\hline \multirow{5}{*}{$\begin{array}{l}\text { preventive } \\
\text { treatment of } \\
\text { accidental wounds }\end{array}$} & none & 25 & 32 & 68 & \multirow{5}{*}{0.026} \\
\hline & covering with soil & 48 & 46 & 54 & \\
\hline & sodium hypoclorite & 17 & 41 & 59 & \\
\hline & cupric and/or slaked lime & 10 & 80 & 20 & \\
\hline & other & 7 & 86 & 14 & \\
\hline
\end{tabular}


Table 2 - Relationship between the incidence of blight and the age of the orchard and fertilisation levels in Trás-os-Montes. The data refers to 2001/2002

\begin{tabular}{|c|c|c|c|c|}
\hline \multirow[b]{2}{*}{ Variable } & \multicolumn{2}{|c|}{ Mean ( and standard error) } & \multirow[b]{2}{*}{$\mathbf{F}$} & \multirow[b]{2}{*}{$\mathbf{p}$} \\
\hline & $\begin{array}{l}\text { H-orchads } \\
<10 \% \text { trees } \\
\text { infected } \\
n=50\end{array}$ & $\begin{array}{l}\text { D-orchards } \\
>10 \% \text { trees } \\
\text { infected } \\
n=55\end{array}$ & & \\
\hline Mean age of trees (years) & $20.2(1.1)$ & $25.2(1.6)$ & 6.187 & 0.014 \\
\hline Organic amendment (kg/tree) & $22.9(5.6)$ & $46.4(10.3)$ & 3.736 & 0.056 \\
\hline Organic amendment $\left(\mathrm{kg} / \mathrm{m}^{2}\right)^{\mathrm{a}}$ & $0.55(0.1)$ & $1.24(0.3)$ & 4.340 & 0.040 \\
\hline $\mathrm{N}$ from fertiliser (g/tree) & $40.0(12.0)$ & $96.9(22.9)$ & 4.568 & $\mathbf{0 . 0 3 5}$ \\
\hline $\mathrm{N}$ from fertiliser $\left(\mathrm{g} / \mathrm{m}^{2}\right)^{\mathrm{a}}$ & $1.4(0.4)$ & $2.6(0.6)$ & 2.837 & 0.095 \\
\hline $\mathrm{N}$ from organic amendment ( $\mathrm{g} /$ tree $)$ & $198.5(49.1)$ & $319.1(72.4)$ & 1.826 & 0.180 \\
\hline $\mathrm{N}$ from organic amendment $\left(\mathrm{g} / \mathrm{m}^{2}\right)^{\mathrm{a}}$ & $5.6(1.4)$ & $14.5(4.2)$ & 3.749 & 0.056 \\
\hline $\mathrm{N}$ from (fertiliser + organic amendment) $(\mathrm{g} /$ tree $)$ & $238.6(49.2)$ & $416.0(84.2)$ & 3.146 & 0.079 \\
\hline $\mathrm{N}$ from (fertiliser + organic amendment) $\left(\mathrm{g} / \mathrm{m}^{2}\right)^{\mathrm{a}}$ & $6.9(1.4)$ & $17.1(4.4)$ & 4.408 & $\mathbf{0 . 0 3 8}$ \\
\hline $\mathrm{P}_{2} \mathrm{O}_{5}$ from organic amendment (g/tree) & $34.4(8.6)$ & $62.6(13.9)$ & 2.822 & 0.096 \\
\hline $\mathrm{P}_{2} \mathrm{O}_{5}$ from organic amendment $\left(\mathrm{g} / \mathrm{m}^{2}\right)^{\mathrm{a}}$ & $1.0(0.3)$ & $2.0(0.4)$ & 4.010 & 0.048 \\
\hline $\mathrm{P}_{2} \mathrm{O}_{5}$ from (fertiliser + organic amendment) $(\mathrm{g} /$ tree $)$ & $51.0(9.2)$ & $101.3(22.0)$ & 4.166 & 0.044 \\
\hline $\mathrm{P}_{2} \mathrm{O}_{5}$ from (fertiliser + organic amendment) $\left(\mathrm{g} / \mathrm{m}^{2}\right)^{\mathrm{a}}$ & $1.7(1.4)$ & $3.2(0.8)$ & 3.284 & 0.073 \\
\hline $\mathrm{K}_{2} \mathrm{O}$ from organic amendment $\left(\mathrm{g} / \mathrm{m}^{2}\right)^{\mathrm{a}}$ & $5.2(1.3)$ & $16.4(5.8)$ & 3.297 & 0.072 \\
\hline $\mathrm{K}_{2} \mathrm{O}$ from (fertiliser + organic amendment $)\left(\mathrm{g} / \mathrm{m}^{2}\right)^{\mathrm{a}}$ & $6.3(1.3)$ & $18.5(6.0)$ & 3.632 & 0.059 \\
\hline
\end{tabular}

\footnotetext{
a - per unit of canopy projection area
} 